\title{
Assessment of Waste Generation rate of Medical Hazardous in Duhok Governorate (Proposal of alternative disposal and management methods)
}

\author{
Maha M. AL-Ghabban ${ }^{1}$, Nashwan Shawkat Mizzouri², Fadhil Rashid Mahmood ${ }^{3}$, Hussein Hamid Hassan ${ }^{4}$, Kadhim \\ Ibrahim Abdulrahman ${ }^{5}$ \\ College of Engineering, University of Duhok, Duhok, Kurdistan Region - Iraq
}

\begin{abstract}
The developments and improvement of the public and the private healthcare sector in the recent years in Duhok governorate considered as the main factor for increasing the production rate of per capita patient generation of hazardous waste (Bio-Medical Waste). Another important factor contributes in hazardous waste volume is the increase in health services and public education. Generation of waste caused direct impacts on human health and environment through the pollution of soil, water and air. The present study was carry out to assess the sources and the data quantities of hazardous wastes, analysis of these collected data is achieved by using of GIS Application. In 2014, it was found that 253.143 tons of hazardous waste were produced in Duhok. About $30 \%$ of the waste is not being sorted from the municipal solid waste, i.e. disposed directly to dumps or landfills. Inadequate disposal of hazardous waste can related to contamination of surface and ground water supplies, and risk impacts on communities and their environment. In addition the aim of this assessing is focused on the importance of hazardous waste management and to develop a proposal for treatment and disposal management methods in compliance with the international environmental regulations.
\end{abstract}

KEYWORDS : Medical Hazardous Waste, Waste Management, Waste Generation, Landfills, recycling.

\section{INTRODUCTION}

At the beginning of the 1980s, a definition of hazardous waste was recognized in the USA. It involves all constituents that are hazardous to environment and to the human health. Most industrialized countries have proven laws that control various production of harmful waste to protect the environment and the public health. While other countries implement either the recommendations of Environmental Protection Agency (EPA) as their standards or the standards of the World Health Organization (WHO) (Marinković et al., 2008). EPA has involved the hospital wastes within the hazardous waste (Bennett, 1992). Furthermore, WHO has stated that this waste should be treated as special waste (Rushbrook, 2000). Medical waste contains

Academic Journal of Nawroz University (AJNU)

Volume 7, No 4 (2018).

Regular research paper : Published 21 December 2018

Corresponding author's e-mail :

maha.alghabban@uod.ac Copyright (C2017 Maha M.

AL-Ghabban1, Nashwan Shawkat Mizzouri2, Fadhil

Rashid Mahmood3, Hussein Hamid Hassan4, Kadhim

Ibrahim Abdulrahman5. This is an open access article

distributed under the Creative Commons Attribution

License. constituents that are created in the facilities of medical treatment, health protection and scientific research; the category is called health care or medical waste (Ropeik and Gray, 2002). The main sources for generation of medical waste are health centers, hospitals, research laboratories, clinics, nursing homes, autopsy centers, mortuaries, and transfusion and hemodialysis centers. In addition, a small quantity of medical waste is produced in dental and general practitioner offices. Some of the medical waste is comparable to the domestic waste such as: food waste, paper, glass, and cardboard. While some other contains infectious, harmful, toxic, and carcinogenic materials and is considered as hazardous waste (Marinković et al., 2008). Baveja et al. (2000) declared that medical waste consists of human tissues or body parts, sharp parts, and infectious materials. Shinee et al. (2008) stated that 15$25 \%$ of medical waste is infectious materials. Chartier (2014) indicated that medical wastes contain high level of heavy metals including mercury due to broken medical equipment. The composition of medical wastes depends on the type of medical facilities, practice procedure, and clinic specialty. The waste generation 
rates may range between 0.11 and $3.9 \mathrm{~kg} / \mathrm{bed} /$ day at hospitals of Canada, Turkey, India, Japan, Bangladesh, and Thailand (Mohee, 2005). While it ranges between 0.25 and $7.0 \mathrm{~kg} /$ bed/day in US and many European countries (Liberti et al., 1996). The private hospitals in Jordon had a lower average waste production rate (4.02 $\mathrm{kg} /$ patient/day) than the public hospitals (6.10 $\mathrm{kg} /$ patient/day) (Bdour et al., 2007). Chung and Lo (2003) stated that the waste generation is $0.4-5.5$ $\mathrm{kg} /$ patient/day in 12 developed and developing countries. Abdulla et al. (2008) mentioned that inappropriate waste management can cause potential effects such as growth of worms, rodents, and insects in addition to unpleasant odors and it may lead to spread of diseases such as hepatitis, cholera, and typhoid. Almuneef and Memish (2003) declared that when the quantity and the complexity of the medical waste increases, the risk of conveying diseases through unsafe handling practices also increases such diseases as Hepatitis B and C and AIDS (Almuneef and Memish, 2003). Jang et al. (2006) declared that in South Korea they use a number of treatment methods for medical waste including steam sterilization, microwave sanitation, incineration, dry heat disinfection, and chemical disinfection. Currently steam sterilization and incineration are the main treatment methods. Tudor et al. (2005) stated that the quantity and the risks associated with the handling of medical wastes can be reduced significantly with appropriate resource recycling and separation. Sabour et al. (2007) confirmed that the quantity of infectious waste can be decreased by $15.1 \%$ only because infectious wastes were collected and separated correctly. Marinković et al. (2008) discussed medical waste management in Croatia, they referred that the management is depending on the waste category hence pathological waste, involving the recognizable material (fetuses and amputated parts) these can be buried in cemeteries or incinerated in crematoria due to ethical reasons. On the other hand, the unrecognizable material (body parts, blood, and tissue samples,) these can be incinerated with other infectious waste. Regarding the packaging for medical wastes, all packages should be labeled as "Hazardous medical waste", yellow color indicated chemical waste, blue and black indicate general waste, green is used for pharmaceutical waste, red marks infectious waste, red with a black stripe point toward pathological waste. In developed countries, the best technologies are used for disposal of medical wastes with insignificant risks to the environment and human health. They use the regulations to follow several possible ways for storage, transport, collection, and disposal of such wastes (Tudor et al., 2005). On the other hand, in many developing countries, they still dispose the medical and hazardous waste together with the separation wastes, consequently creating an excessive effect on the environment, the public, and specifically on the health of the municipal workers (Tudor et al., 2005). Furthermore, the management of the wastes that generated by clinics, and hospitals has not been comprehensively understood. The laborers who perform the management of the medical waste are not sufficiently protected and (Diaz et al., 2005). Therefore, research is required to create a database about the medical waste generation, sources, transportation, collection, and disposal. Moreover, recording the composition and quantities are required to help for the planning and implementing the medical waste management. The objectives of this paper are to evaluate the medical waste production from different institutions in Duhok governorate (including hospitals and laboratories - governmental and private), to assess the available procedures, methods, and techniques of disposal and handling of medical waste and to suggest the proper management and treatment of medical waste.di

\section{STUDY AREA AND METHODOLOGY 2.1 Study Area}

Duhok governorate is located north of Iraq and the study area included Duhok city and other sub-districts such as Shekan, Summel, Zakho, Ammadia, Aqri, and Bardarash. Since 2012, Duhok Governorate has hosted large numbers of internal displacement persons and Syrian refugees. Consequently, the healthcare institutions served more patients and the medical waste generation increased rapidly. The directorate of Environment in Duhok city distributed a questionnaire to 111 healthcare institutions in Duhok governorate at the end of 2014 (with total of 3511326 patients who visited these institutions during this year). It was included for example: weight of the hazardous waste, weight of the general waste, methods of disposal and treatment, and number of patients. The healthcare institutions included 72 health centers, 14 governmental hospitals, 18 governmental specialist centers, 5 private hospitals, 1 blood center bank, and 1 health central laboratory. See fig.1 The hazardous waste were including: medicine waste, waste of X-ray films, radioactive waste, waste that is containing mercury, waste of medical equipment, waste that is containing chemical solutions, amalgam waste, and expired medicines. The indicators the generation rate of medical solid waste is expressed by $\mathrm{kg} /$ patient/ day were found by dividing the annual amount of generated waste over the annual visited patients and then divided by 365 days. 


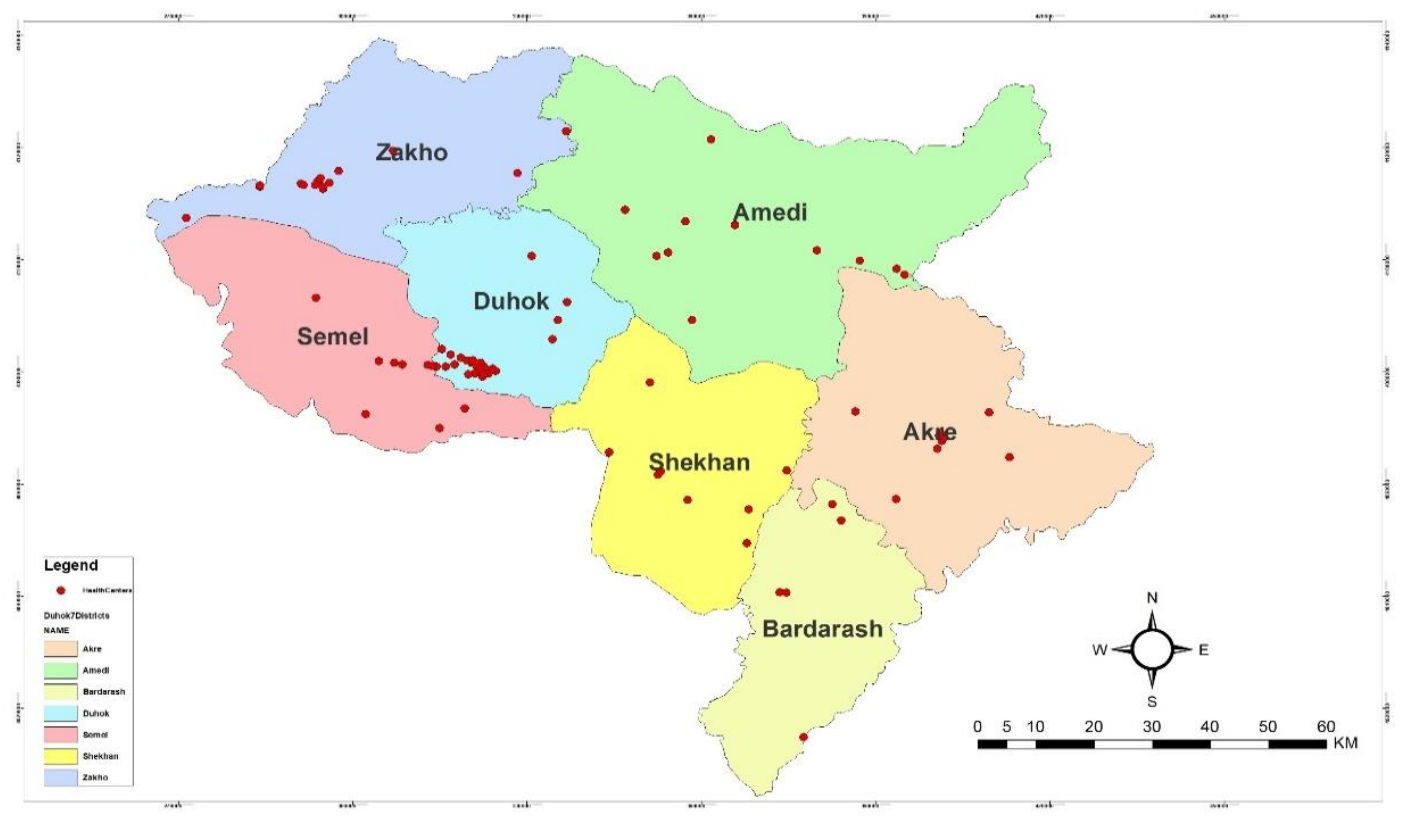

Fig (1) : Distribution of healthcar facilites within the study area

\subsection{Data Analysis}

Data analysis is achieved by using a geographical information system ArcGIS software to map the hospital location included in this stud, and to create relations between the numbers of patients and the generation rate of the medical hazardous waste.

\section{RESULTS AND DISCUSSION}

\subsection{Rate of Generation}

According to the WHO fact Sheet the sources of the medical hazardous waste (MHW) is health care activities, $80 \%$ is about municipal waste (MW) and the remaining $20 \%$ is MHW (WHO, 2018). The annual generation rate for the medical hazardous waste
(MHW) and the municipal waste are given in table 1 (appendix A). The rates represented results from surveying of seven districts in Duhok governorate. The MW contents represents $93 \%$ and about $7 \%$ for the medical waste, the difference from the WHO fact sheet is attributed to the neglect of the sorting process between the medical and municipal waste in many districts and districts as Amadi and Aqura. The rate of MHW were different from one hospital to another depending on the types and specialty, and number of patients or No. of beds. See Fig. 2.

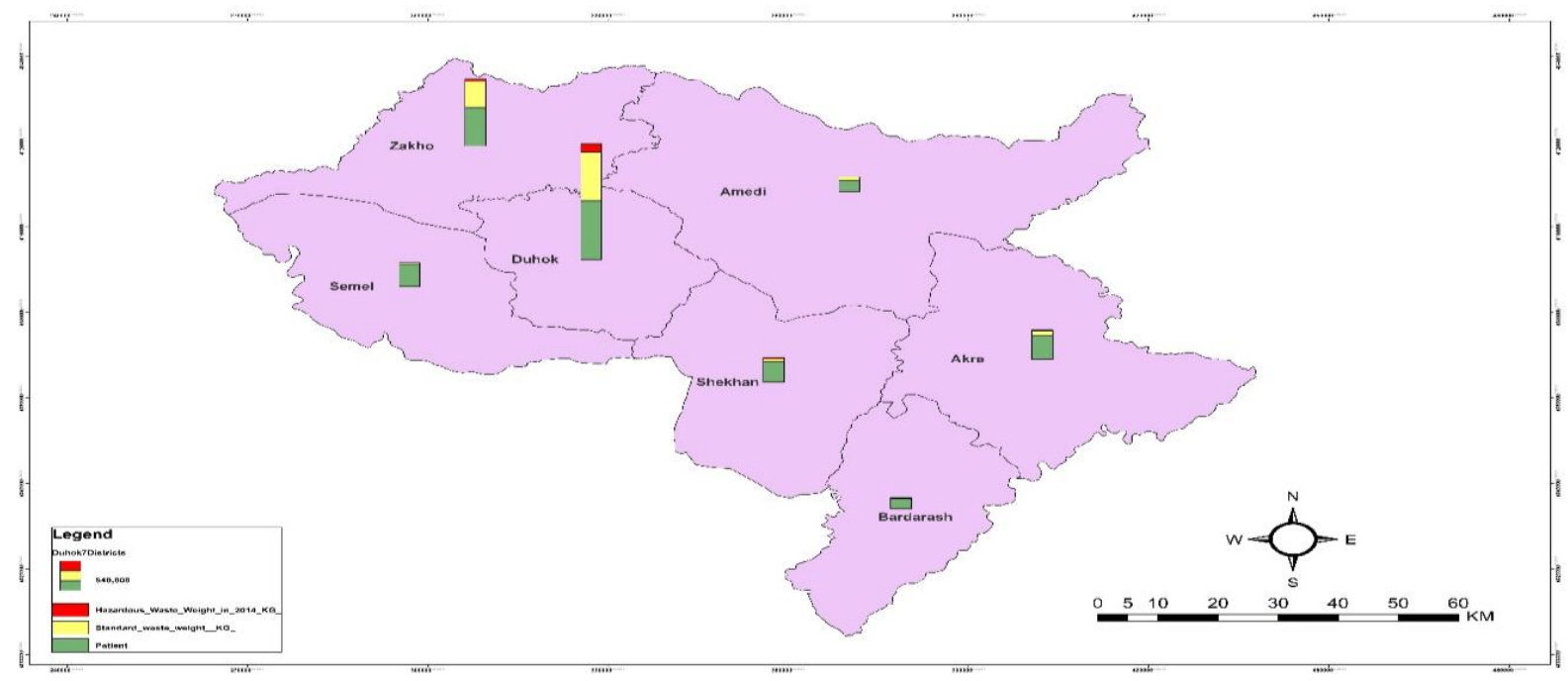

Fig (2) : Quantities of hazardous waste and the miniciple waste in Duhok (kg/yr) relative to No. of patients The figure summarizes the per year quantities of MHW, records 4 ton/year, fig. 3 the total was found $253,143 \mathrm{~kg} /$ year (= 255 ton /year). Duhok approached the maximum records (165 ton/year) while Barderash showed the minimum 


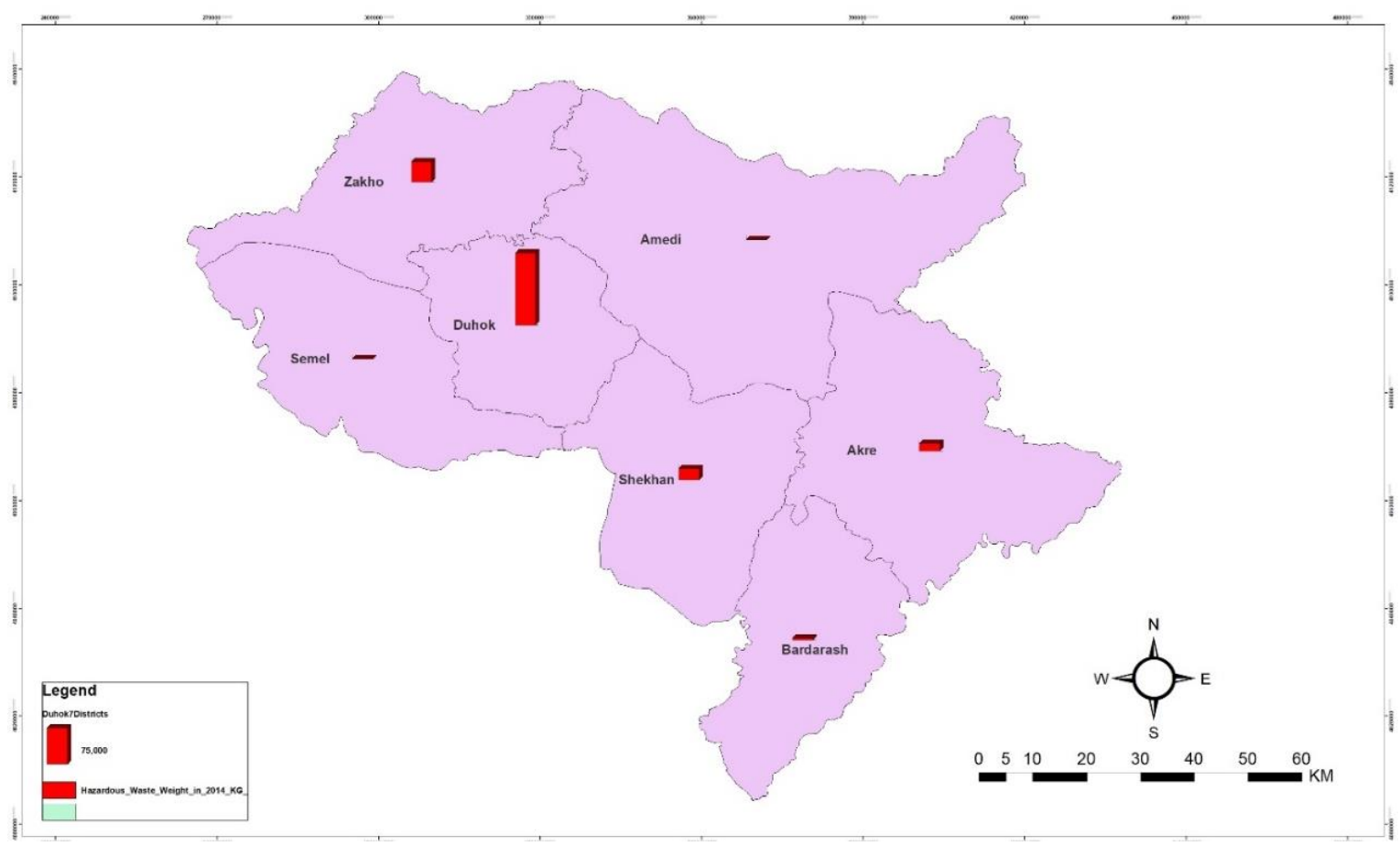

Fig (3) : Weight of MHW at Duhok districts (kg/yr) in 2014

The positive increase between the number of patients, the quantities of the municipal solid waste and the quantities of the MHW generated is reviewed in figures 4 and 5. Depending on this bases the indicator for rate of medical waste generation $\mathrm{kg} /$ patient/day can be derived and found to be equal (0.000187245) $\mathrm{kg} /$ patient/day. This quantity is not identical and considered negligible compared with studies achieved by many researchers who have found the average rate of MHW produced in Saudi Arabia the generation rate of health care risk waste was $1.13+0.96 \mathrm{~kg} / \mathrm{bed} /$ day (AlZahrani M.A. \& Fakhr, 2000), 0.5 to $2.5 \mathrm{~kg} /$ bed/day for northern hospitals in Jordan whereas in Amman hospitals the reported quantity was $3.4 \mathrm{~kg} /$ bed/day (Thakir et al., 2013), while in some hospitals in Najaf city/Iraq the rate estimated as 1.074 to 3.844 $\mathrm{kg}$ /capita/day (Fatima, 2016). A studies in Isfahan, India, and Turkey found the generation rate equal to $(1.59 \mathrm{~kg} /$ day/bed), $2 \mathrm{~kg} / \mathrm{bed} /$ day, $2.5 \mathrm{~kg} / \mathrm{bed} /$ day, respectively, (Ferdosi et al., 2012), (Akkoyunlu et al, 2017), (Quarii et al, 2013). The incompatibility results can be explained referring to patients data which includes both the inpatients and outpatients, while other studies considered the No. of beds.

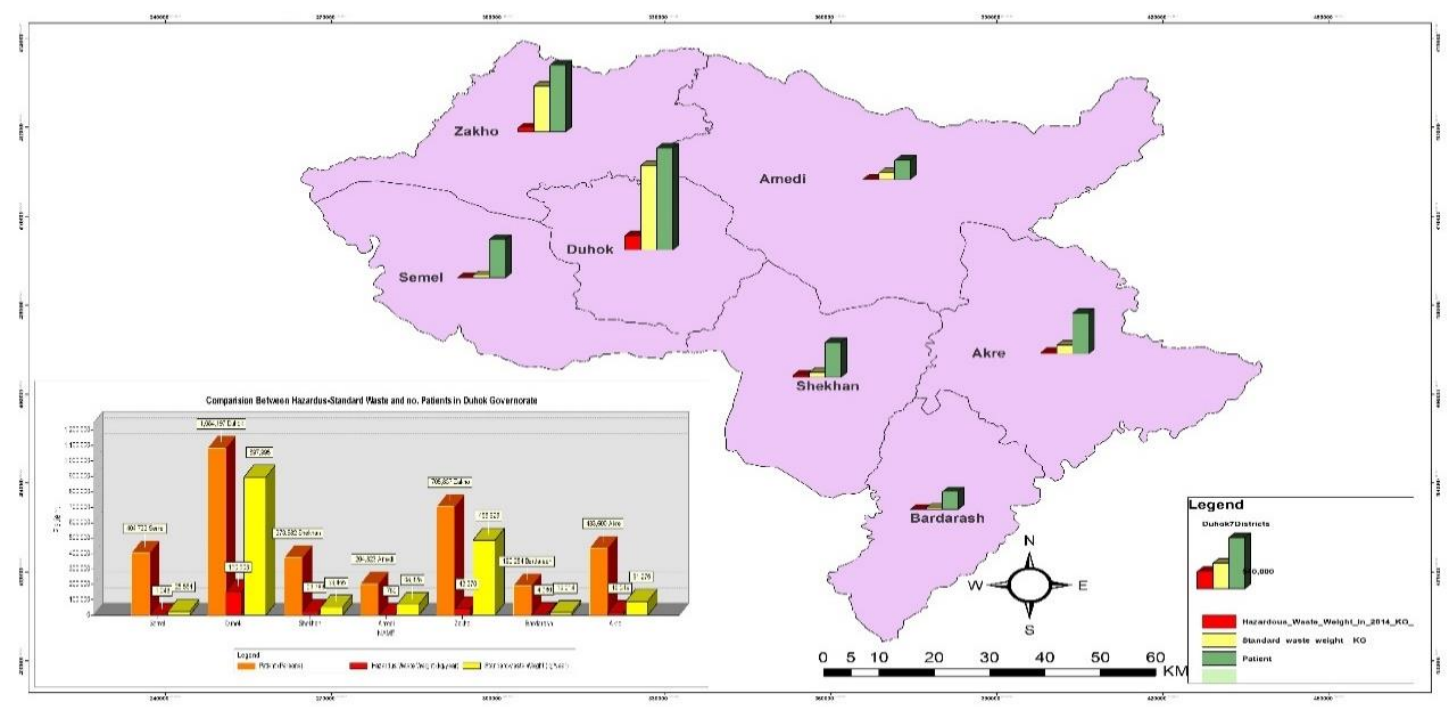

Fig (4) : Comparsion between the number of patients and the generated MHW in Duhok governorate in 2014 


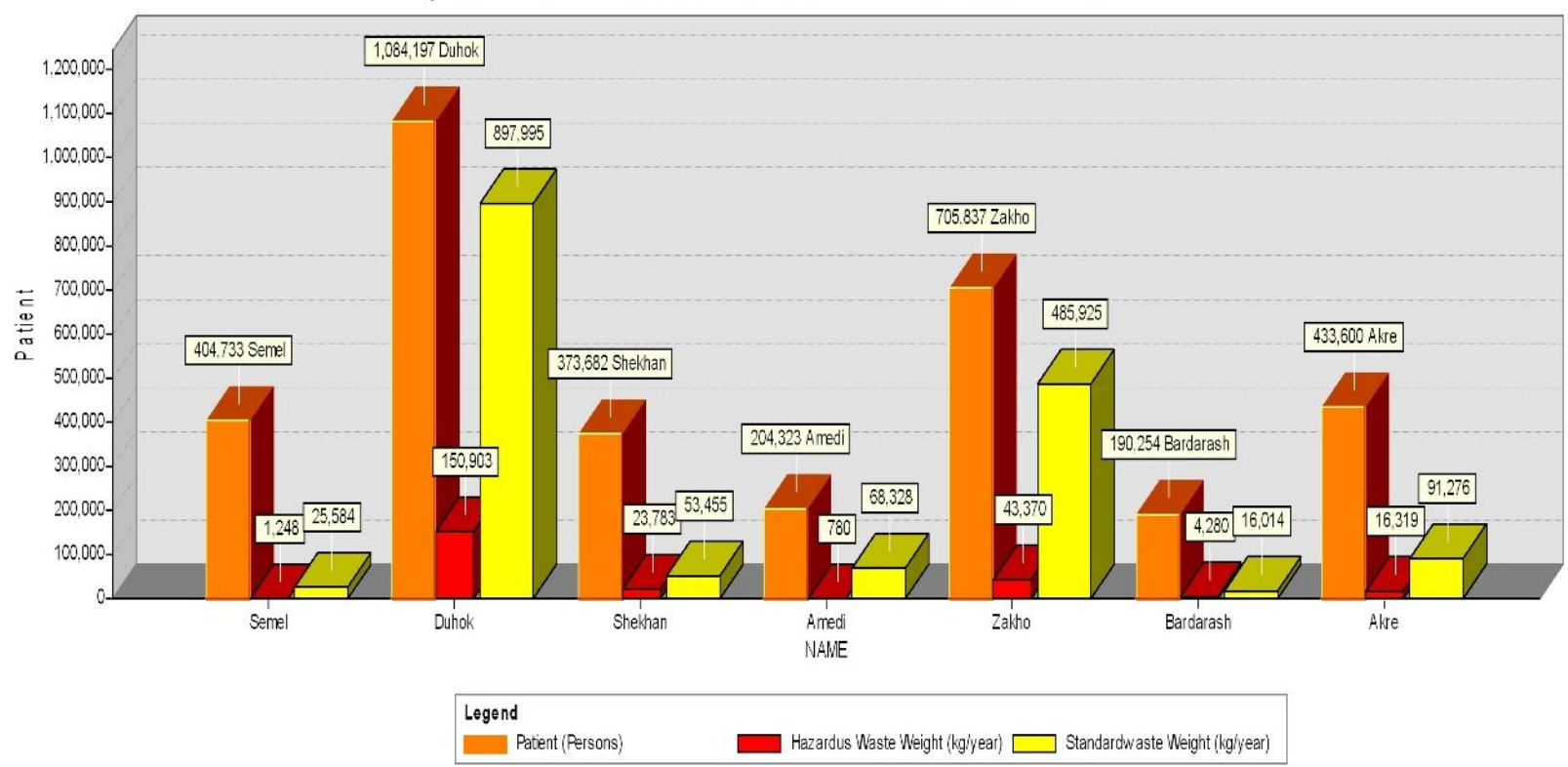

Fig (5) : Comparsion between the number of patients and the generated MHW in Duhok governorate in 2014

\subsection{Correction of The Generation Rate Per Patient}

The number of patients with the daily MHW generation indicator can be corrected depending on the number of beds in healthcare facilities in Duhok, Table 2 identified the relation between bed numbers and the generated waste in $\mathrm{kg} / \mathrm{bed} /$ day. The average daily generation was estimated in this research and it was found to be equal to $0.27 \mathrm{~kg} / \mathrm{bed} /$ day (the last two columns in the table), this value is approximately equal to estimated value by Mohee (Mohee, 2005), though is relatively lower than estimations of USA $4.5 \mathrm{~kg} / \mathrm{bed} /$ day, France $2.5 \mathrm{~kg} / \mathrm{bed} /$ day, and Netherlands $2.7 \mathrm{~kg} / \mathrm{bed} /$ day
(Fakher, 2008). As it compared with the WHO regulations, the value is classified as low hazard waste (Al-Zahrani M.A. \& Fakhr, 2000), ( low hazard values less than $0.3 \mathrm{~kg} / \mathrm{bed} /$ day, meduim hazard values less than 0.3 to $0.4 \mathrm{~kg} / \mathrm{bed} /$ day, and $0.4605 .5 \mathrm{~kg} /$ bed/day (Al-Zahrani M.A. \& Fakhr, 2000). The result considered true when the treatment and disposal processes subject to separation and sorting but in fact most of the healthcare facilities in Duhok are not undergone to such processes.

Table (2) : Average medical hazardous waste generation per bed; [Directorate of Environment in Duhok]

\begin{tabular}{|c|c|c|c|c|c|c|c|}
\hline No. & Health care Facility & Province & $\begin{array}{c}\text { Beds } \\
\text { No. }\end{array}$ & $\begin{array}{c}\text { Hazardous } \\
\text { waste } \mathbf{W t} \\
(\mathbf{K g} / \mathbf{y r})\end{array}$ & $\begin{array}{c}\text { Municipal } \\
\text { Solid waste } \\
\text { Wt (Kg/yr) }\end{array}$ & $\begin{array}{c}\text { Average } \\
\text { HW } \mathbf{\text { bed/day }}\end{array}$ & $\begin{array}{c}\text { \% } \\
\text { HW to } \\
\text { MSW }\end{array}$ \\
\hline 1 & Azadi Teaching Hospital & Duhok & 450 & 16,585 & 432,000 & 0.10 & 3.84 \\
\hline 2 & $\begin{array}{c}\text { Emergency Education } \\
\text { Hospital }\end{array}$ & Duhok & 174 & 10,820 & 74,880 & 0.17 & 14.45 \\
\hline 3 & $\begin{array}{c}\text { Hifi Children's Educational } \\
\text { Hospital }\end{array}$ & Duhok & 256 & 18,615 & 109,500 & 0.20 & 17.00 \\
\hline 4 & Obstetrics Hospital & Duhok & 140 & 14,606 & 73,000 & 0.29 & 20.01 \\
\hline 5 & $\begin{array}{c}\text { Burns \& Plastic Surgery } \\
\text { Hospital }\end{array}$ & Duhok & 53 & 1,261 & 4,065 & 0.07 & 31.02 \\
\hline 6 & Ophthalmology Hospital & Duhok & 13 & 5,007 & 3,120 & 1.07 & 0.00 \\
\hline 7 & Teaching Hospital / zakho & Zakho & 205 & 12,775 & 365,000 & 0.17 & 3.50 \\
\hline 8 & Emergency Hospital /Zakho & Zakho & 125 & 9,125 & 14,600 & 0.20 & 62.50 \\
\hline 9 & Obstetrics Hospital /Zakho & Zakho & 60 & 14,600 & 65,700 & 0.68 & 22.22 \\
\hline
\end{tabular}




\begin{tabular}{|c|c|c|c|c|c|c|c|}
\hline 10 & $\begin{array}{c}\text { Amidi Child Friendly } \\
\text { Hospital }\end{array}$ & Amadi & 65 & 780 & 46,800 & 0.03 & 1.67 \\
\hline 11 & Rojanna Hospital & Amadi & 7 & 0 & 4,680 & 0.00 & 0.00 \\
\hline 12 & Kulan General Hospital & aqura & 105 & 7,665 & 43,800 & 0.20 & 17.50 \\
\hline 13 & $\begin{array}{c}\text { Emergency and Obstetrics } \\
\text { Hospital / Aqra }\end{array}$ & Aqura & 74 & 8,030 & 21,900 & 0.30 & 36.67 \\
\hline
\end{tabular}

\section{Reference}

3.3 Current hazardous waste management in Duhok Most of the hospitals and health centers in Duhok don't have clear management for the disposal and management of MHW. The waste were collected and transported without separation and disposed with municipal solid to dumps or uncontrolled landfills. The summary in table 3 showed the general methods of MHW used in Duhok treatment, it is appearing there is approximately $27 \%$ of the total was collected and burned in randomly in simple pits either onsite or out

Table (3) : Codes for hazardous waste treatment methods; [Directorate of Environment in Duhok] site, $4 \%$ of the total have been sterilized inside the healthcare facility with autoclaves. About $3.6 \%$ of the MHW were transported to central incineration, $8 \%$ were transported and buried in landfills, and about $19 \%$ were discharged directly to the local sewage system, the other $12 \%$ were treated by on site incineration, while the remaining $30 \%$ has no sorting and disposed along with the municipal solid waste.

\begin{tabular}{|c|c|c|c|}
\hline $\begin{array}{l}\text { Code } \\
\text { No. }\end{array}$ & Health Care Facility & $\begin{array}{l}\text { Code } \\
\text { No. }\end{array}$ & $\begin{array}{c}\text { Methods of Disposal or } \\
\text { Treatment }\end{array}$ \\
\hline 1 & Using of insite Incineration & 13 & Impermeable On site bore \\
\hline 2 & Centeral outsite inceneration & 14 & Encapsulation \\
\hline 3 & $\begin{array}{l}\text { Random burining without } \\
\text { incinerator }\end{array}$ & 15 & Delivered to Contractor \\
\hline 4 & Autoclave disinfection & 16 & Returned back to the Source \\
\hline 5 & Collection separately & 17 & Selling (after treatment) \\
\hline 6 & $\begin{array}{l}\text { Duming or burned by the } \\
\text { municipality }\end{array}$ & 18 & $\begin{array}{l}\text { Delivered to Competent } \\
\text { authority }\end{array}$ \\
\hline 7 & $\begin{array}{l}\text { Transport to hazardous } \\
\text { waste disposal }\end{array}$ & 19 & Chemical disinfection \\
\hline 8 & $\begin{array}{l}\text { Dischardged dierctlty to the } \\
\text { sewage system }\end{array}$ & 20 & Heat or steam disinfection \\
\hline 9 & $\begin{array}{l}\text { Partially treatment in the } \\
\text { treatment plant }\end{array}$ & 21 & Micrpwave disinfection \\
\hline 10 & $\begin{array}{l}\text { treatment in the treatment } \\
\text { plant }\end{array}$ & 22 & Inertization \\
\hline 11 & $\begin{array}{l}\text { On site bore for burrying and } \\
\text { burning waste }\end{array}$ & 23 & Other methods \\
\hline 12 & Treatment and recycling & & \\
\hline
\end{tabular}




\subsection{Management Plan for Medical Hazardous Waste}

WHO in their report Management of Solid Health-Care at primary care centers suggested seven fundamentals elements for integrated management of medical solid waste (WHO, 2018). These elements are Waste Minimization, Separation, Codification, Handling, Transportation, Treatment, and Disposal.

A brief definition of each elements for the integrated management of medical solid waste are indicated at the (appendix B)

\subsection{General Technologies in The Medical Hazardous} Waste (Diaz et al, 2005)

a. Shredding or removal of needles from the syringes (after disinfection)

b. Encapsulation (or solidification) of sharps

c. Disinfection: were performed by Steam/thermal, Autoclave, Microwave, and Chemical

d. Incineration: it is a burning process used for treatment of the infectious waste and removal of pathogens, the benefits of incineration is volume reduction of the waste with less toxic emissions. Main methods of incineration are uncontrolled included Open pit and Burning, and Controlled which included small incinerator, and large incinerator. Uncontrolled incineration should be avoided because of the toxic gas emissions and incompletely burned of the infectious waste, while the disadvantages of the controlled incineration are the needs for skilled workers and big funds and operating cost.

e. Landfills: two main categories of landfills uncontrolled, and controlled (Santosh Vani et al, 2017). Form it is name uncontrolled landfills are open dumping not recommended for the medical waste because open dumps have not managed and control for the toxic waste and the entry of unofficial persons. Controlled landfills ranged from small pits to the significant sanitary landfills, they are central municipal facility, and contrary to uncontrolled landfills these enhanced the toxic waste control and secured lands (Shreedevi, 2007) .

\subsection{Suggested Management and planning for Medical hazardous wastes in Duhok}

Continuing disposal of waste cause risk to the society and the environment, so its recommended to develope a management and planning for the treatment and disposal of the medical hazardous waste. the management plan should be consider the quanities and the charecteristics of the waste. The main points included are:

1. Enacted Rules and regulations; Waste management should be meet the national and local regulations. And to participate with environmentalists and municipalities to enforce regulations and rules, and the choice of waste disposal facilities.

2.Training of healthcare staff; it is recommended to perform the separation process, and to plan for the training of workers in safe handling and storage of HMW

3. Implementation processes; the separation process of the infectious waste from the medical waste should be applied, taking into account the color coding of waste.

4. Choice of appropriate methods of treatment and disposal techniques;

There is no particular methods appropriate for the treatment of medical waste, it depends upon the generated quantities and the local regulations, for this study we suggest using both the onsite and offsite methods as follows.

\section{OnsiteTreatment}

a. Incineration is a common onsite method, and can be divide into three catogries Low temperatures incineration $\left(400^{\circ}-800^{\circ} \mathrm{C}\right)$, medium temperatures $\left(800^{\circ}\right.$ $\left.-1000^{\circ} \mathrm{C}\right)$, and high tempreatures $\left(>1000^{\circ} \mathrm{C}\right)$. low and medium incinerations are low cost construction, provided complete sterlization for the non plastic infectious, sharps and anatomical waste, reduced weight and volume of the waste (Klangisn, 2011). Toxic emmisions considered the main disadvantage that causes widespeard health impacts, so the high efficiency air pollution equipments installed to reduce toxic emissions (EPA, 2003). It is recommended to participate the municipalities to designate the combustion zone. Whereas High temperatures incineration $\left(>1000^{\circ} \mathrm{C}\right)$ are relatively high cost construction, required trained staff for operation and manitanence, and it is appropriate sterlization of all waste types. It provides complete combustion with $50 \mathrm{~kg}$ to $500 \mathrm{~kg} /$ hour performance efficiency. Inicinerations of such type are highly reduces the waste volume and the toxic emissions. Environmentalists and minicipalities contributed in the selection of incineration locations so that meet the local regualtions to reduce the waste risk.

b. Microwave: is other onsite treatment techniques have been recommended for the sterlization of the infectious sharps materials, microwaves are effective in the volume reduction of waste.

c. Steam autocalve: its applicable in the sterilization many types of waste, different from incineration and microwave by waste shrinkage approximately $30 \%$ of the volume, and low environmental impacts and operating cost. Studies indicated that sterilization by microwave and autoclave are sufficient technologies (Klangisn, 2011) (WHO., 2005), with disadvantage of need additional treatment to improve the efficiency by supplement of shredding, which increase the waste reduction by $60-80 \%$

Offsite Treatment (Landfill disposal)

a.Sanitary landfills considered an effective choice for 
waste disposal after it has been treated as incineration ash, pathological waste, etc. Landfills represented the final process in the suggested medical waste management treatment and disposal stated for this study. A problem raised from medical waste contained in the landfill which is groundwater pollutions caused by the leachate, this indicates the need to use onsite treatment by autoclave before disposal. Landfill sites are selected under the control of municipalities, it is required organized transportation, operation and maintenance, and training staff to prevent health risk. b. Recyclable plastics and syringes: Recent studies indicated the possibilities of recycling the medical waste after sterilization to reduce the waste quantities and the negative impacts on the environment and public health (Klangisn, 2011). Electro-Thermal-Deactivation (ETD used as sterilization technique appropriate most the categories of the medical waste. Recyclable plastics and syringes, glass wares are separated after sterilization and transported to plastics recycling factories, while the non-recyclable materials are shredded, bagging and transported to landfills as typical solid waste.

\section{CONCLUSION}

According to the data, analyzed above, the medical waste generation form hospitals in Duhok governorate was about 250,000 kg/year (250 ton/year), and the approximate estimation of the generation rate was 0.27 $\mathrm{kg} / \mathrm{bed} /$ day which is considered acceptable in comparison with results of the local research's and the international approaches. The most common treatment was carried out by randomly burning and disposed to open dumps with the usual solid waste. Another observation through the data shows that $30 \%$ of hospitals were not subject to the process of sorting out medical waste from typical waste. Other observation resolved in this study is about $30 \%$ from the total hospitals included in the study have no sorting from the usual solid waste, this revealed that most healthcare institutes in Duhok have incompetence in the medical waste management, consequently the need for the implementation of the waste management hierarchy is essential. The main hierarchy goals is the reduction, reuse and recycle of the waste, in order to mitigate the inverse environmental impacts and the health risks, On this bases the development of a guidelines and regulations as strategy for the separation process at the source of generation, followed by using the color coding for the different types of waste. Rehabilitation and maintenance of the exiting incinerators is required for the treatment of infectious waste. Further studies are required, specifically in the infectious waste comprises radioactive materials, and the assessments of environmentalists and the municipalities responsible for the safe waste management.

\section{APPENDIX (A)}

Table (1) : Annule quantitities of the medical health care hazardous waste in Dohuk Governorate 2014/Iraq/ KurdustanRegion; [Directorate of Environment in Duhok]

\begin{tabular}{|c|c|c|c|c|c|c|c|c|}
\hline & Health Care Facility & $\begin{array}{c}\text { Governo } \\
\text { rate }\end{array}$ & Patients & Staff & $\begin{array}{c}\text { Medical } \\
\text { Hazardo } \\
\text { us waste } \\
\mathbf{W t} \\
\mathbf{K g} / \mathbf{y r})\end{array}$ & $\begin{array}{c}\text { Disposal } \\
\text { Methods }\end{array}$ & $\begin{array}{c}\text { Municip } \\
\text { al Solid } \\
\text { waste Wt } \\
\mathbf{( K g} / \mathbf{y r})\end{array}$ & $\begin{array}{c}\text { Disposal } \\
\text { Methods }\end{array}$ \\
\hline 1 & $\begin{array}{c}\text { Central Public Health } \\
\text { Laboratory }\end{array}$ & Duhok & 51668 & 16 & 5,436 & 3 & 5,436 & 7 \\
\hline 2 & $\begin{array}{c}\text { Mental Health Center } \\
\text { Duhok }\end{array}$ & 1824 & 3 & 290 & 7 & 1,740 & 7 \\
\hline 3 & $\begin{array}{c}\text { Specialized Dental } \\
\text { Center }\end{array}$ & Duhok & 46877 & 43 & 2,900 & 10 & 6,340 & 7 \\
\hline 4 & $\begin{array}{c}\text { Consulting center for } \\
\text { tuberculosis and }\end{array}$ & Duhok & 1472 & 1 & 317 & 10 & 1,585 & 7 \\
\hline 5 & $\begin{array}{c}\text { The detection Center } \\
\text { for early disabilities }\end{array}$ & Duhok & 9680 & 9 & 0 & 0 & 4,350 & 7 \\
\hline 6 & $\begin{array}{c}\text { Center for Arthritis } \\
\text { Diseases and Medical }\end{array}$ & Duhok & 51299 & 11 & 0 & 0 & 17,400 & 7 \\
\hline 7 & $\begin{array}{c}\text { Zaneen Center for } \\
\text { School Health }\end{array}$ & Duhok & 18792 & 5 & 317 & 8 & 1,585 & 7 \\
\hline
\end{tabular}




\begin{tabular}{|c|c|c|c|c|c|c|c|c|}
\hline 8 & $\begin{array}{l}\text { Zain Center for } \\
\text { Hematology and }\end{array}$ & Duhok & 2957 & 4 & 580 & 3 & 5,220 & 3 \\
\hline 9 & $\begin{array}{c}\text { Synthetic kidney } \\
\text { center and lithotripsy }\end{array}$ & Duhok & 21665 & 7 & 7,925 & 3 & 7,925 & 7 \\
\hline 10 & $\begin{array}{c}\text { Duhok Diabetes } \\
\text { Center }\end{array}$ & Duhok & 47500 & 6 & 1,558 & 10 & 1,902 & 7 \\
\hline 11 & $\begin{array}{c}\text { Xanast Family } \\
\text { Medicine Center }\end{array}$ & Duhok & 20625 & 5 & 317 & 3 & 6,340 & 7 \\
\hline 12 & $\begin{array}{c}\text { Center of } \\
\text { Gastroenterology and }\end{array}$ & Duhok & 4670 & 8 & 4,350 & 10 & 1,450 & 7 \\
\hline 13 & $\begin{array}{l}\text { Eazyadi Center for } \\
\text { Cardiology and }\end{array}$ & Duhok & 2026 & 17 & 9,510 & 10 & 4,755 & 10 \\
\hline 14 & $\begin{array}{l}\text { Children's Surgery } \\
\text { Center / M.Hevi for }\end{array}$ & Duhok & 5065 & 9 & 0 & 0 & 3,170 & 7 \\
\hline 15 & $\begin{array}{l}\text { Eazyadi Center for } \\
\text { cancer diseases }\end{array}$ & Duhok & 3235 & 4 & 145 & 3 & 580 & 7 \\
\hline 16 & $\begin{array}{c}\text { Center for } \\
\text { Tuberculosis and }\end{array}$ & Duhok & 2138 & 2 & 317 & 10 & 1,585 & 7 \\
\hline 17 & Thalassemia Center & Duhok & 12744 & 6 & 3,804 & 10 & 1,585 & 7 \\
\hline 18 & $\begin{array}{c}\text { Azadi Specialist } \\
\text { Center for Infertility }\end{array}$ & Duhok & 200 & 3 & 365 & 10 & 2,190 & 7 \\
\hline 19 & $\begin{array}{c}\text { Directorate of } \\
\text { Forensic Medicine }\end{array}$ & Duhok & 3074 & 4 & 1,825 & 10 & 2,555 & 7 \\
\hline 20 & Central Blood Bank & Duhok & 31053 & 1 & 13,140 & 10 & 3,650 & 7 \\
\hline 21 & $\begin{array}{c}\text { Azadi Teaching } \\
\text { Hospital }\end{array}$ & Duhok & 63400 & 370 & 16,585 & 3 & 432,000 & 7 \\
\hline 22 & $\begin{array}{c}\text { Emergency } \\
\text { Education Hospital }\end{array}$ & Duhok & 82994 & 66 & 10,820 & 3 & 74,880 & 7 \\
\hline 23 & $\begin{array}{c}\text { Hifi Children's } \\
\text { Educational Hospital }\end{array}$ & Duhok & 101602 & 49 & 18,615 & 3 & 109,500 & 7 \\
\hline 24 & $\begin{array}{c}\text { Burns \& Plastic } \\
\text { Surgery Hospital }\end{array}$ & Duhok & 4468 & 10 & 1,261 & 3 & 4,065 & 7 \\
\hline 25 & Obstetrics Hospital & Duhok & 48955 & 72 & 14,606 & 3 & 73,000 & 7 \\
\hline 26 & $\begin{array}{c}\text { Ophthalmology } \\
\text { Hospital }\end{array}$ & Duhok & 36239 & 18 & 5,007 & 3 & 3,120 & 7 \\
\hline 27 & $\begin{array}{c}\text { Yamidi Child } \\
\text { Friendly Hospital }\end{array}$ & Amadi & 17281 & 12 & 780 & 7 & 46,800 & 7 \\
\hline 28 & Rosanna Hospital & Amadi & 9685 & 3 & 0 & 0 & 4,680 & $4 a 7$ \\
\hline 29 & $\begin{array}{c}\text { Emergency Hospital } \\
\text { /Zakho }\end{array}$ & Zakho & 130343 & 50 & 9,125 & 1 & 14,600 & 7 \\
\hline 30 & $\begin{array}{c}\text { Obstetrics Hospital } \\
\text { /Zakho }\end{array}$ & Zakho & 61977 & 11 & 14,600 & 3 & 65,700 & 7 \\
\hline
\end{tabular}




\begin{tabular}{|c|c|c|c|c|c|c|c|c|}
\hline 31 & $\begin{array}{c}\text { Heaching Hospital / } \\
\text { zakho }\end{array}$ & Zakho & 91806 & 64 & 12,775 & 1 & 365,000 & 7 \\
\hline 32 & $\begin{array}{l}\text { Kulan General } \\
\text { Hospital }\end{array}$ & Auqra & 80996 & 71 & 7,665 & 3 & 43,800 & 7 \\
\hline 33 & $\begin{array}{c}\text { Emergency and } \\
\text { Obstetrics Hospital }\end{array}$ & Auqra & 203364 & 16 & 8,030 & 3 & 21,900 & 7 \\
\hline 34 & Shekhan Hospital & Sheikhan & 166667 & 32 & 18,250 & 1 & 29,200 & 7 \\
\hline 35 & $\begin{array}{c}\text { Duhok Private } \\
\text { Hospital }\end{array}$ & Duhok & 1776 & 5 & 624 & 3 & 3,120 & 7 \\
\hline 36 & $\begin{array}{l}\text { Shilan Private } \\
\text { Hospital }\end{array}$ & Duhok & 240 & 4 & 3,120 & 2 & 12,480 & 7 \\
\hline 37 & $\begin{array}{c}\text { Xian Privaye } \\
\text { Hospital }\end{array}$ & Zakho & 857 & 4 & 1,825 & 3 & 730 & 7 \\
\hline 38 & $\begin{array}{l}\text { Vin National } \\
\text { Hospital }\end{array}$ & Duhok & 387 & 12 & 9,360 & 10 & 21,840 & 7 \\
\hline 39 & $\begin{array}{l}\text { Vajin National } \\
\text { Hospital }\end{array}$ & Duhok & 421 & 22 & 6,240 & 3 & 15,600 & 7 \\
\hline 40 & $\begin{array}{l}\text { Mateen Health } \\
\text { Center }\end{array}$ & Duhok & 15865 & 5 & 936 & 3 & 1,500 & 7 \\
\hline 41 & Duhok Health Center & Duhok & 21797 & 3 & 986 & 3 & 11,232 & 7 \\
\hline 42 & $\begin{array}{l}\text { Shrhldan Health } \\
\text { Center }\end{array}$ & Duhok & 40054 & 3 & 624 & 10 & 624 & $4 \mathrm{~A} 7$ \\
\hline 43 & $\begin{array}{l}\text { Barazan Health } \\
\text { Center }\end{array}$ & Duhok & 23570 & 4 & 0 & 0 & 4,056 & 7 \\
\hline 44 & $\begin{array}{l}\text { Sheedan Health } \\
\text { Center }\end{array}$ & Duhok & 28913 & 4 & 0 & 0 & 1,872 & 3 \\
\hline 45 & $\begin{array}{l}\text { Khabat Health } \\
\text { Center }\end{array}$ & Duhok & 114700 & 5 & 12,460 & 3 & 3,560 & 7 \\
\hline 46 & Malta Health Center & Duhok & 37809 & 4 & 0 & 0 & 4,680 & 7 \\
\hline 47 & $\begin{array}{l}\text { Mankesh Health } \\
\text { Center }\end{array}$ & Duhok & 17738 & 2 & 634 & 1 & 951 & 7 \\
\hline 48 & $\begin{array}{l}\text { Khadiy Mohammad } \\
\text { Health Center }\end{array}$ & Duhok & 40215 & 5 & 936 & 10 & 6,240 & 7 \\
\hline 49 & $\begin{array}{c}\text { Bakerat Health } \\
\text { Center }\end{array}$ & Duhok & 13200 & 2 & 952 & 1 & 3,170 & 7 \\
\hline 50 & $\begin{array}{c}\text { Kourt Kafta Health } \\
\text { Center }\end{array}$ & Duhok & 31040 & 1 & 634 & 10 & 951 & 7 \\
\hline 51 & Zawita Health Center & Duhok & 17816 & 2 & 2,538 & 1 & 3,170 & 7 \\
\hline 52 & $\begin{array}{l}16 \text { AAB Health } \\
\text { Center }\end{array}$ & Duhok & 7780 & 10 & 0 & 0 & 1,248 & 7 \\
\hline 53 & $\begin{array}{c}\text { Bahdinan Health } \\
\text { Center }\end{array}$ & Duhok & 23524 & 6 & 624 & 10 & 4,992 & 7 \\
\hline
\end{tabular}




\begin{tabular}{|c|c|c|c|c|c|c|c|c|}
\hline 54 & $\begin{array}{l}11 \text { Aadhar Health } \\
\text { Center }\end{array}$ & Duhok & 34926 & 6 & 624 & 10 & 2,808 & 7 \\
\hline 55 & Zanko Health Center & Duhok & 6663 & 1 & 156 & 10 & 12,480 & 7 \\
\hline 56 & $\begin{array}{c}\text { Shindokha Health } \\
\text { Center }\end{array}$ & Duhok & 33831 & 4 & 0 & 0 & 468 & 7 \\
\hline 57 & $\begin{array}{l}\text { Prison duhok } 1 \\
\text { Health Center }\end{array}$ & Duhok & 1215 & 14 & 365 & 3 & 365 & 7 \\
\hline 58 & $\begin{array}{l}\text { Shaheed Mohammad } \\
\text { Salah Buty Health }\end{array}$ & Duhok & 9195 & 6 & 1,560 & 3 & 6,240 & 7 \\
\hline 59 & $\begin{array}{l}\text { Kolaan Health } \\
\text { Center }\end{array}$ & Sumeal & 66553 & 15 & 0 & 0 & 10,920 & 7 \\
\hline 60 & $\begin{array}{l}\text { Sharyha Health } \\
\text { Center }\end{array}$ & Sumeal & 68612 & 2 & 0 & 0 & 936 & 1 \\
\hline 61 & Ashty Health Center & Sumeal & 40609 & 4 & 624 & 7 & 936 & 7 \\
\hline 62 & $\begin{array}{l}\text { Tanahy Health } \\
\text { Center }\end{array}$ & Sumeal & 31228 & 2 & 0 & 0 & 1,872 & 7 \\
\hline 63 & Batyle Health Center & Sumeal & 15571 & 1 & 0 & 0 & 936 & 7 \\
\hline 64 & $\begin{array}{l}\text { Doban Health } \\
\text { Center }\end{array}$ & Sumeal & 40499 & 6 & 312 & 4 & 2,496 & 7 \\
\hline 65 & $\begin{array}{l}\text { Khanka Health } \\
\text { Center }\end{array}$ & Sumeal & 85522 & 2 & 0 & 0 & 3,120 & 7 \\
\hline 66 & $\begin{array}{l}\text { Avrocity Health } \\
\text { Center }\end{array}$ & Sumeal & 11775 & 1 & 312 & 8 & 1,248 & 7 \\
\hline 67 & Fydaa Health Center & Sumeal & 44364 & 6 & 0 & 0 & 3,120 & 7 \\
\hline 68 & Bottan Health Center & Amadi & 24842 & 2 & 0 & 0 & 312 & 7 \\
\hline 69 & $\begin{array}{l}\text { Sursunk Health } \\
\text { Center }\end{array}$ & Amadi & Stopped & 0 & 0 & 0 & 0 & - \\
\hline 70 & $\begin{array}{l}\text { Khadash Health } \\
\text { Center }\end{array}$ & Amadi & 20401 & 3 & 0 & 0 & 936 & 7 \\
\hline 71 & $\begin{array}{c}\text { Dera Lok Health } \\
\text { Center }\end{array}$ & Amadi & 24500 & 3 & 0 & 0 & 5,616 & 7 \\
\hline 72 & $\begin{array}{c}\text { Shella Deyzi Health } \\
\text { Center }\end{array}$ & Amadi & 23782 & 5 & 0 & 0 & 3,120 & 7 \\
\hline 73 & Syre Health Center & Amadi & 14605 & 1 & 0 & 0 & 1,248 & 7 \\
\hline 74 & $\begin{array}{l}\text { Bamerny Health } \\
\text { Center }\end{array}$ & Amadi & 8189 & 1 & 0 & 0 & 312 & $4 a 7$ \\
\hline 75 & Gara Health Center & Amadi & 42154 & 5 & 0 & 0 & 3,120 & $7 \mathrm{a} 4$ \\
\hline 76 & $\begin{array}{c}\text { Cha Mangea Health } \\
\text { Center }\end{array}$ & Amadi & 12699 & 1 & 0 & 0 & 936 & 7 \\
\hline
\end{tabular}




\begin{tabular}{|c|c|c|c|c|c|c|c|c|}
\hline 77 & Hete Health Center & Amadi & 6185 & 1 & 0 & 0 & 1,248 & $4 a 7$ \\
\hline 78 & $\begin{array}{l}\text { Atroosh Health } \\
\text { Center }\end{array}$ & Sheikhan & 6555 & 1 & 317 & 10 & 634 & 7 \\
\hline 79 & $\begin{array}{l}\text { Khsrook Health } \\
\text { Center }\end{array}$ & Sheikhan & 54000 & 3 & 1,095 & 1 & 3,650 & 7 \\
\hline 80 & Chera Health Center & Sheikhan & 14420 & 1 & 1,585 & 1 & 1,585 & 7 \\
\hline 81 & Kelkjy Health Center & Sheikhan & 85000 & 2 & 951 & 1 & 9,510 & 7 \\
\hline 82 & $\begin{array}{c}\text { Ba-Athera Health } \\
\text { Center }\end{array}$ & Sheikhan & 2500 & 4 & 0 & 0 & 4,755 & 10 \\
\hline 83 & Rekva Health Center & Sheikhan & - & - & 0 & 0 & 0 & - \\
\hline 84 & $\begin{array}{c}\text { Shekhan Health } \\
\text { Center }\end{array}$ & Sheikhan & 38040 & 3 & 951 & 10 & 951 & 10 \\
\hline 85 & $\begin{array}{l}\text { Mahad Complex } \\
\text { Health Center }\end{array}$ & Sheikhan & 6500 & 2 & 634 & 1 & 3,170 & 7 \\
\hline 86 & $\begin{array}{c}\text { Khabor Health } \\
\text { Center }\end{array}$ & Zakho & 82639 & 6 & 1,248 & 3 & 6,240 & 7 \\
\hline 87 & Dalall Health Center & Zakho & 30562 & 4 & 312 & 3 & 936 & 7 \\
\hline 88 & $\begin{array}{c}\text { Nowroz Health } \\
\text { Center }\end{array}$ & Zakho & 77725 & 3 & 312 & 3 & 9,360 & 7 \\
\hline 89 & $\begin{array}{c}\text { Tal-Akabar Health } \\
\text { Center }\end{array}$ & Zakho & 41977 & 3 & 312 & 3 & 3,120 & 7 \\
\hline 90 & Darker Health Center & Zakho & 22670 & 3 & 312 & 4 & 1,872 & 7 \\
\hline 91 & $\begin{array}{c}\text { Batoofa Health } \\
\text { Center }\end{array}$ & Zakho & 13754 & 3 & 365 & 2 & 3,650 & 7 \\
\hline 92 & $\begin{array}{c}\text { Derboon Health } \\
\text { Center }\end{array}$ & Zakho & 29473 & 1 & 936 & 3 & 4,680 & 7 \\
\hline 93 & $\begin{array}{l}\text { Rerzgry Health } \\
\text { Center }\end{array}$ & Zakho & 18090 & 0 & 312 & 3 & 1,248 & 7 \\
\hline 94 & $\begin{array}{c}\text { Bekoofa Health } \\
\text { Center }\end{array}$ & Zakho & 14209 & 3 & 312 & 4 & 312 & 7 \\
\hline 95 & $\begin{array}{c}\text { Said Beran Health } \\
\text { Center }\end{array}$ & Zakho & 39208 & 3 & 312 & 2 & 3,120 & 7 \\
\hline 96 & $\begin{array}{l}\text { The Haram Al- } \\
\text { Kamruki Health }\end{array}$ & Zakho & 18203 & 1 & 0 & 0 & 365 & 7 \\
\hline 97 & $\begin{array}{l}\text { Shehdan (Barazn) } \\
\text { Health Center }\end{array}$ & Zakho & 32344 & 3 & 312 & 3 & 4,992 & 7 \\
\hline 98 & Auqra Health Center & Auqra & 14574 & 2 & 0 & 0 & 4,360 & 7 \\
\hline 99 & Azadi Health Center & Auqra & 30690 & 2 & 0 & 0 & 12,480 & 7 \\
\hline
\end{tabular}




\begin{tabular}{|c|c|c|c|c|c|c|c|c|}
\hline $\begin{array}{c}10 \\
0\end{array}$ & $\begin{array}{l}\text { Dinertaa Health } \\
\text { Center }\end{array}$ & Auqra & 37936 & 1 & 312 & 7 & 1,560 & 7 \\
\hline $\begin{array}{c}10 \\
1\end{array}$ & Byjel Health Center & Auqra & 7811 & 1 & 312 & 7 & 624 & 7 \\
\hline $\begin{array}{c}10 \\
2\end{array}$ & $\begin{array}{l}\text { Kurdseen Health } \\
\text { Center }\end{array}$ & Auqra & 23236 & 1 & 0 & 0 & 1,248 & 7 \\
\hline $\begin{array}{c}10 \\
3\end{array}$ & $\begin{array}{l}\text { Meer Haj Health } \\
\text { Center }\end{array}$ & Auqra & 5320 & 1 & 0 & 0 & 936 & 7 \\
\hline $\begin{array}{c}10 \\
4\end{array}$ & $\begin{array}{l}\text { Sherman Health } \\
\text { Center }\end{array}$ & Auqra & 19585 & 1 & 0 & 0 & 2,496 & 7 \\
\hline $\begin{array}{c}10 \\
5\end{array}$ & $\begin{array}{c}\text { Shehdan Health } \\
\text { Center }\end{array}$ & Auqra & 3115 & 4 & 0 & 0 & 624 & 7 \\
\hline $\begin{array}{c}10 \\
6\end{array}$ & $\begin{array}{l}\text { Maheta Health } \\
\text { Center }\end{array}$ & Auqra & 6973 & 1 & 0 & 0 & 1,248 & 7 \\
\hline $\begin{array}{c}10 \\
7\end{array}$ & $\begin{array}{c}\text { Barderash Health } \\
\text { Center }\end{array}$ & $\begin{array}{c}\text { Barderas } \\
\mathrm{h}\end{array}$ & 66927 & 6 & 1,825 & 3 & 7,300 & 7 \\
\hline $\begin{array}{c}10 \\
8\end{array}$ & $\begin{array}{c}\text { Khazer Health } \\
\text { Center }\end{array}$ & $\begin{array}{c}\text { Barderas } \\
\mathrm{h}\end{array}$ & 32188 & 4 & 951 & 1 & 4,755 & 7 \\
\hline $\begin{array}{c}10 \\
9\end{array}$ & $\begin{array}{l}\text { Omer Sina Health } \\
\text { Center }\end{array}$ & $\begin{array}{c}\text { Barderas } \\
\mathrm{h}\end{array}$ & 6245 & 1 & 290 & 1 & 870 & 7 \\
\hline $\begin{array}{c}11 \\
0\end{array}$ & Kalak Health Center & $\begin{array}{c}\text { Barderas } \\
\mathrm{h}\end{array}$ & 58927 & 5 & 634 & 2 & 2,219 & 7 \\
\hline $\begin{array}{c}11 \\
1\end{array}$ & $\begin{array}{c}\text { Roovyha Health } \\
\text { Center }\end{array}$ & $\begin{array}{c}\text { Barderas } \\
\mathrm{h}\end{array}$ & 25967 & 2 & 580 & 1 & 870 & 7 \\
\hline
\end{tabular}

\section{APPENDIX (B);}

Definition of the elements of the integrated management of medical solid waste by WHO:

Waste minimization

Referred to the elimination of the waste production or its reduction. Waste reduction include as stated in the WHO report modification of marketing measures, elimination of the products of toxic materials.

\section{Separation}

Its process to reduce the hazardous waste quantities by separation into sharps, infectious non-sharps and nonhazardous waste.

\section{Codification}

Waste should be stored in color coding system either containers or bags. Yellow or red usually for infectious waste and black for non-infectious waste.

\section{Handling}

WHO reported that handling includes the collection, weighing and storing conditions, time for storing shouldn't exceed 24 hours.

\section{Treatment}

WHO defined treatment as a method and technique of any process to change the physical, chemical, biological characteristic or composition of any biomedical waste so as to reduce impacts of waste to non-hazardous to health and environment.

\section{Disposal}

Represents the final location of the treated waste. Landfills whether controlled or uncontrolled is the most general method of disposal.

\section{REFERENCES}

1.Abdulla, F., Qdais, H. A., \& Rabi, A. (2008). Site investigation on medical waste management practices in northern Jordan. Waste Management, 28(2), 450-458.

2. Almuneef, M., \& Memish, Z. A. (2003). Effective medical waste management: it can be done. American journal of infection control, 31(3), 188-192

3. Al-Zahrani, M. S. A. (2000). Health care risk waste in Saudi Arabia. Saudi Medical Journal, Vol. 21 (3) pp 245250.

4. Baveja, G., Muralidhar, S., \& Aggarwal, P. (2000). Hospital waste management-an overview. Hospital today, 5(9), 485-486.

5. Bdour, A., Altrabsheh, B., Hadadin, N., \& Al-Shareif, M. (2007). Assessment of medical wastes management practice: A case study of the northern part of Jordan. Waste Management, 27(6), 746-759.

6. Bennett, G. (1992). Medical waste management and disposal: by US Environmental Protection Agency, VJ Landrum, RG Barton, R. Neulicht, M. Turner, D. Wallace and S. Smith, published by Noyes Data 
Corporation, Park Ridge, NJ, 1991, ISBN 0-8155-1264-3, 541 pp., \$82.00: Elsevier

7. Chartier, Y. (2014). Safe management of wastes from health-care activities: World Health Organization.

8.Chung, S.-s., \& Lo, C. W. (2003). Evaluating sustainability in waste management: the case of construction and demolition, chemical and clinical wastes in Hong Kong. Resources, Conservation and Recycling, 37(2), 119-145.

9.Drews, F.A., Pasupathi, M., \& Strayer, D.L. (2008). Passenger and cell phone conversations in simulated driving. Journal of Experimental Psychology: Applied, 14, 392-400. doi: 10.1037/a0013119

10. Diaz et al, L. S. (2005). Alternatives for the tretment and disposal of healthcare. waste managemnt, 626-637.

11. EPA, s. 4. (2003). Dioxin: Conitinuing EPA Efforts to Reduce the Pubibc Exposure to Dioxin Risks. Washington, DC: United States Office of Research Environmental Protection and Development.

12. Fakher, J. A. (2008). Healthcare waste mangment in Jordan King Abdullah University hospital case syudy. Umm Al-Quraa, J.Sci. Med. Eng., Vol.20 No.1, pp.61-77.

13. Fatima, M. K. (2016). Evaluation of Medical solid wastes managment in some hospitals in Najaf city/Iraq. Kufa Journal of engineering, Vol. 7, No. 3, P.P. 38-54.

14. Jang, Y.-C., Lee, C., Yoon, O.-S., \& Kim, H. (2006). Medical waste management in Korea. Journal of Environmental Management, 80(2), 107-115.

15. Klangisn, P. H. (2011). Medical waste Treatment and Disposal Methods used by Hospitals in Oregon, Washington, and Idaho. Journal of the Air \& waste management Association, 516-526.

16. Liberti, L., Tursi, A., Costantino, N., Ferrara, L., \& Nuzzo, G. (1996). Optimization of infectious hospital waste management in Italy: Part II. Waste characterization by origin. Waste management \& research, 14(5), 417-431.

17. Marinković, N., Vitale, K., Holcer, N. J., Džakula, A., \& Pavić, T. (2008). Management of hazardous medical waste in Croatia. Waste Management, 28(6), 1049-1056.

18. Mohee, R. (2005). Medical waste charecterisation in healthcare institution in mauritius. Waste management, 25(6), 575-581.

19. Ropeik, D., \& Gray, G. M. (2002). Risk: a practical guide for deciding what's really safe and what's dangerous in the world around you: Houghton Mifflin Harcourt.

20. Rushbrook, P. (2000). Starting health care waste management in medical institutions OMS health care waste practical information series (Vol. 1): OMS.

21. Sabour, M. R., Mohamedifard, A., \& Kamalan, H. (2007). A mathematical model to predict the composition and generation of hospital wastes in Iran. Waste Management, 27(4), 584-587.

22. Santosh Vani, S. B. (2017). Hazardous Waste- Impact on Health and Environment for sustainble devleopment in Indai. WSN, 158-172.

23. Shinee, E., Gombojav, E., Nishimura, A., Hamajima, N., \& Ito, K. (2008). Healthcare waste management in the capital city of Mongolia. Waste Management, 28(2), 435-441.

24. Shreedevi, D. (2007). Hazardous waste managment at the healthcare facilities. India: http://www.indus.org/healthcare.

25. Tudor, T., Noonan, C., \& Jenkin, L. (2005). Healthcare waste management: a case study from the National Health Service in Cornwall, United Kingdom. Waste Management, 25(6), 606-615.

26. HO. (2018). WHO Fact sheet. http : // www.healthcarewaste.org.

27. WHO. (2005). Management of Solid Health-Care Waste at Primary Health-care Centers. Geneve, Switzerland: WHO Document Production Services. 